\title{
The Role of Independent Activities in
}

Development of Strategic Learning

Competences and Increase of School

Performance Level, within the Study of High School Pedagogy

Monica-Iuliana Anca \& Muşata Bocoş 


\title{
The Role of Independent Activities in Development of Strategic Learning Competences and Increase of School Performance Level, within the Study of High School Pedagogy
}

\author{
Monica-Iuliana Anca ${ }^{a^{*}}$, Muşata Bocoşs ${ }^{b}$ \\ aDoctoral School „Educational, Reflection, Development”, Babes-Bolyai University, 7 Sindicatelor Street, 400029, Cluj-Napoca, \\ Romania \\ ${ }^{b}$ Babes-Bolyai University, Faculty of Psychology and Educational Sciences, Educational Sciences Departament, 7 Sindicatelor Street, \\ 400029, Cluj-Napoca, Romania \\ *Corresponding author: moni_anca@yahoo.com
}

Abstract

Keywords:

Independent activities Strategic learning Competence Collective reflection Cognitive and metacognitive reflection

Zusammenfasung

Schlüsselworte:

Selbstständige Aktivitäten; Strategisches Lernen; strategische Lernkompetenz; Individuelle und kollektive Reflexion;

Kognitive und metakognitive Reflexion
The experimental research performed by us with the purpose of exploring the possibilities of development of strategic learning competences and improvement of school performance of $11^{\text {th }}$ grade students, pedagogical profile, specialisation in primary school-kindergarten teacher, falls in the category of researches aiming to make efficient certain didactical strategies by testing new action methods. In this proposed subject, which is of great interest, we tried to offer the teaching staff support in performing student-focused activities, which would stimulate them and raise awareness, as well as shape them as self-sufficient persons, capable of setting goals and of reflecting, individually, as well as collectively, upon strategies chosen to reach those aims.

The data achieved and processed with the SPSS programme have revealed that the educational programme created by us, systemic and focused on independent activities, which valorise the individual, collective, cognitive and meta-cognitive reflection, inputs to shaping the strategic learning competence and facilitates the improvement of their school performance.

Die von uns durchgeführte experimentelle Forschung zur Erforschung der Entwicklungsmöglichkeiten der strategischen Lernkompetenz und der Verbesserung der Schulleistungen bei den Schülern der 11. Klasse, Fachgebiet: Pädagogik, Ausbildung: Unterstufenlehrer-Kindergärtnerin, gehört zur Kategorie der Forschungen, die auf die Steigerung der Effizienz von didaktischen Strategien durch das Experimentieren neuer Handlungsmodelle abzielen. Durch das vorgeschlagene Thema, das aktuell ist, haben wir es versucht den Lehrern die Möglichkeit zu geben, Tätigkeiten auszuführen, die sich auf die Schüler konzentrieren, sie motivieren und sie verantwortlich machen und sie als unabhängige Personen bilden, die fähig sind sich Ziele zu setzen, und sowohl individuell als auch kollektiv auf die gewählten Strategien zur Erreichung dieser Ziele zurückzugreifen. Die gewonnenen Daten, die mit dem SPSSProgramm verarbeitet wurden, ergaben, dass das von uns systematisch konzipierte Bildungsprogramm, das auf selbstständige Aktivitäten beruht, die die individuelle und kollektive, kognitive und metakognitive Reflexion valorisieren und zur Gestaltung der strategischen Lernkompetenz beiträgt und zur Verbesserung ihrer Schulleistung führt.

\section{Introduction}

The current reform in education promotes a series of pedagogical practices focused on students and on learning activity performed individually or in collaboration with others, highlighting the importance of what and how the student learned and how did he collaborate with others in the learning process.

A student who learns actively and interactively is his own initiator and organiser of the learning experiences, capable to permanently reorganise and restructure his own acquirements, in systemic vision. Through active learning we aim that students will gradually become capable to elaborate personalised individual learning projects, to assume responsibility for and to acknowledge them, to apply, evaluate, improve, monitor, manage and self-adjust learning by progressively achieving autonomy in learning and formation (M.-D. Bocoş, 2013, p. 86).

The competences of learning to learn fall into the category of key-competences and refer to an individual's ability to think and efficiently coordinate the learning processes, to have a good time and information management, individually and in group. These competences imply a good self-knowledge of the self-learning needs, as well as of the possibilities to get involved in learning, of the self-motivation capacity to overcome the possible cognitive challenges and obstacles in order to successfully perform the learning tasks and processes (coord. M.-D. Bocoş, 2015, p. 226). 
The strategic learning competence imply choosing and valorisation of the most efficient strategies in order to successfully perform the learning tasks and to cover the learning process, individually, as well as collectively.

\section{Theoretical baselines}

The study and analysis of the specialised bibliography have determined us, through this research, to try to reconfigure the role of the independent activities, by highlighting them in the study of high school pedagogy.

In the Dictionary of Praxiological Pedagogy (coord. M.-D. Bocoss, 2015, p. 38), the term ,independent activity" has the following definition: „The intellectual or psycho-motor activity, individual or collective, based on personal efforts of those who learn, unassisted by teaching staff'. The independent activity may be individual or collective/ in cooperation/ in group (when the activity of the students is organised in groups). The independent activities have complex features: they imply cognitive/ intellectual, psycho-motor, affective and emotional involvement, deep inner reflection, active and motivating learning behaviour, which determine constant cognitive (re)structuring and facilitate the production of something new, original, creative, either at personal level, or at general level. Therefore, independent activities imply self-involvement, self-information, self-organisation, self-learning, self-monitoring, self-suggestion, self-management of the activity. These features constitute a valuable educational instrument and may be used in various didactic informative and formative purposes, namely to achieve a wide range of fundamental objectives: knowledge discovery, recording, consolidation, deepening, synthesise, exemplification, application, revision, gaining intellectual and/ or practical skills and abilities.

Independent activities highlight strategic learning because they involve the analysis of tasks, choosing strategies for approaching tasks, evaluation of the tasks' solving manner, monitoring of performances, by fitting the paradigm of active and interactive pedagogy.

\section{Research methodology}

The didactical experimental research performed was based on a methodology system consisting of: the psycho-pedagogical experiment, questionnaire-based inquiry, observation, the study of products generated by the learning activity, research method of curricular documents and other school documents, knowledge pedagogical tests, methods, techniques and instruments of mathematical-statistical quantitative and qualitative interpretation (M. Bocoş, 2007). The statistical instruments used for data processing were: descriptive statistical analysis, $\mathrm{t}$ test for independent focus groups and t test for dependent focus groups.

The general hypothesis:

In the pedagogy study, applying to $11^{\text {th }}$ grade students, at pedagogical profile, a systemic educational programme, based on systems of independent activities of the students, which explicitly highlight the individual, collective, cognitive and meta-cognitive reflection, inputs to shaping the strategic learning competence and facilitates the improvement of their school performance.

It comprised the following stages: pre-experimental, formative-experimental and post-experimental.

In performing the pedagogical research, we formulated the following research hypothesis:

Table 1. Research variables

\begin{tabular}{l|l}
\hline $\begin{array}{c}\text { Independent research } \\
\text { variable: }\end{array}$ & $\begin{array}{c}\text { Dependent research } \\
\text { variables: }\end{array}$ \\
\hline $\begin{array}{l}\text { Applying to } 11^{\text {th }} \text { grade students, at } \\
\text { pedagogical profile, an educational }\end{array}$ & $\begin{array}{l}\text { V.D.1. development degree of the } \\
\text { strategic learning competence; }\end{array}$ \\
programme, based on systems of \\
independent activities of the \\
students, which explicitly highlight \\
the individual, collective, cognitive \\
and meta-cognitive reflection, \\
within the study pedagogical \\
subjects (Students Class \\
Management).
\end{tabular}

\section{The results obtained and discussions/ the analysis of the results}

We have applied the pre-test both to the experimental focus group, as to the control focus group, with the purpose of identifying the initial level of theoretical and practical knowledge acquired at the pedagogical subjects studied throughout the $1^{\text {st }}$ semester of the $11^{\text {th }}, 9^{\text {th }}$ and $10^{\text {th }}$ grades, as well as for establishing the level of abilities: knowledge and understating of notions specific to pedagogical subjects studied throughout the $1^{\text {st }}$ semester of the $11^{\text {th }}, 9^{\text {th }}$ and $10^{\text {th }}$ grade, as well as explanation and interpretation abilities of the theoretical and practical content of the pedagogical subjects studied throughout the $1^{\text {st }}$ semester of the $11^{\text {th }}$, $9^{\text {th }}$ and $10^{\text {th }}$ grade. 
Table 2. Descriptive statistical data on the initial test of the experimental focus group and of the control focus group

\begin{tabular}{|c|c|c|c|}
\hline \multicolumn{4}{|c|}{ Descriptive statistics } \\
\hline \multicolumn{4}{|c|}{ Initial test grade } \\
\hline & & Validated data & 84 \\
\hline & $\mathrm{N}$ & & \\
\hline & & Missing data & 0 \\
\hline & Average & & 4.2119 \\
\hline & Median & & 4.1000 \\
\hline Experimental & Module (modal value) & & 4.10 \\
\hline \multirow[t]{10}{*}{ focus group } & Standard deviation & & .88142 \\
\hline & Skewness asymmetry coefficient & & .996 \\
\hline & Kurtosis tailedness coefficient & & 3.210 \\
\hline & Minimum & & 2.30 \\
\hline & Maximum & & 8.00 \\
\hline & & Validated data & 81 \\
\hline & $\mathrm{N}$ & & \\
\hline & & Missing data & 0 \\
\hline & Average & & 4.1914 \\
\hline & Median & Control & 4.2000 \\
\hline & Module (modal value) & & 3.60 \\
\hline & Standard deviation & & .96283 \\
\hline ( & Skewness asymmetry coefficient & & .293 \\
\hline & Kurtosis tailedness coefficient & & -.540 \\
\hline & Minimum & & 2.20 \\
\hline & Maximum & & 6.60 \\
\hline
\end{tabular}

In order to compare grades average values at the initial test between the two student focus groups (experimental and control), we used the $t$ test for independent focus groups.

We've started this initiative by testing the variances of the two focus groups, with the help of the Levene test.

Hypotheses of the Levene test:

$\mathrm{H} 0$ (null hypothesis) = the variances of the averages of the two focus groups are homogenous.

$\mathrm{H} 1=$ the variances of the averages of the two focus groups are heterogeneous.
Whereas $\mathrm{p}>\alpha(0.05)$, the $\mathrm{H} 0$ hypothesis is accepted (variances are equal) and the results in the first row of the table with t test are being further read.

T test hypotheses:

H0: there is no significant difference between the two focus groups in what concerns the grades average at the initial test.

H1: there is a significant difference between the two focus groups in what concerns the grades average at the initial test.

Whereas $\mathrm{p}>\alpha(0.05)$, the H0 hypothesis is accepted, meaning there are no significant difference between the two focus groups in what concerns the grades average values at the initial test. 
Therefore, it is determined that the grades average at the initial test for the students in the experimental focus group $(A=4.21)$ is close in value to the average of the students in the control focus group $(A=4.19)$.

After that, we applied to students in the experimental focus group the educational programme developed by us and put into practice as a support Curriculum. After going through the educational programme proposed by us, the students:

- learned to identify key words and phrases specific to the subject „Students`Class Management” (MEC, 2002);

- learned independent learning methods/techniques and applied them in independent activities;

- developed applications by using contents specific to „Students` Class Management" and by applying independent learning methods/ techniques;

- completed reflection/ self-evaluation exercises (with the purpose of strategic learning).

After going through the educational programme, the teaching staff benefited from:
- scientific content useful in teaching the subject „Students Class Management";

- methods/ techniques useful in involving the students in independent activities;

- reflection/ self-evaluation exercises for teaching the students the strategic learning competence.

At the end of the formative phase, the post-test was administered, both to the students in the experimental focus group, as to the ones in control focus group. This test involved the comparative monitoring of the results of the two focus groups, with the purpose of evaluating the impact of the educational programme based on independent activities upon the students in the experimental focus group, from the perspective of valorisation of the individual, collective, cognitive and meta-cognitive reflection, of shaping the strategic learning competence and improvement of their school performance at the subject „Students` Class Management".

Table 3. Descriptive statistical data on the post-test grades of the experimental focus group and of the control focus group

\begin{tabular}{|c|c|c|c|}
\hline \multicolumn{4}{|c|}{ Descriptive statistics } \\
\hline \multicolumn{4}{|c|}{ Post-test grade } \\
\hline & & Validated data & 84 \\
\hline & $\mathrm{N}$ & & \\
\hline & & Missing data & 0 \\
\hline & Average & & 7.3345 \\
\hline & Median & & 7.0000 \\
\hline Experimental & Module (modal value) & & 6.00 \\
\hline \multirow[t]{9}{*}{ focus group } & Standard deviation & & 1.52153 \\
\hline & Skewness asymmetry coefficient & & .087 \\
\hline & Kurtosis tailedness coefficient & & -1.299 \\
\hline & Minimum & & 4.70 \\
\hline & Maximum & & 10.00 \\
\hline & & Validated data & 81 \\
\hline & $\mathrm{N}$ & & \\
\hline & & Missing data & 0 \\
\hline & Average & & 5.9210 \\
\hline \multicolumn{4}{|c|}{ Control focus group } \\
\hline & Median & & 6.0000 \\
\hline & Module (modal value) & & 5.00 \\
\hline & Standard deviation & & 0.94243 \\
\hline
\end{tabular}


Skewness asymmetry coefficient

Kurtosis tailedness coefficient

Minimum

Maximum
9.00

In order to compare grades average values at the post-test between the two student focus groups (experimental and control), we used the $t$ test for independent focus groups.

The result at $t$ test for independent focus groups revealed that the grades average at the post-test for the experimental focus group is significantly different, from statistical point of view, from the grades average at the post-test for the control focus group $(\mathrm{t}=7.122 ; \mathrm{df}=138.305 ; \mathrm{p}<0.001)$. The grades average at the post-test for the students in the experimental focus group was 7.33. The minimum grade was 4.70 and the maximum grade was 10. The students in the control focus group have achieved a 5.92 grades average at the post-test, the minimum grade being 4.50, whereas the maximum grade was 9 .

Table 4. Statistical descriptive data on the comparison between initial test grades and the post-test grades

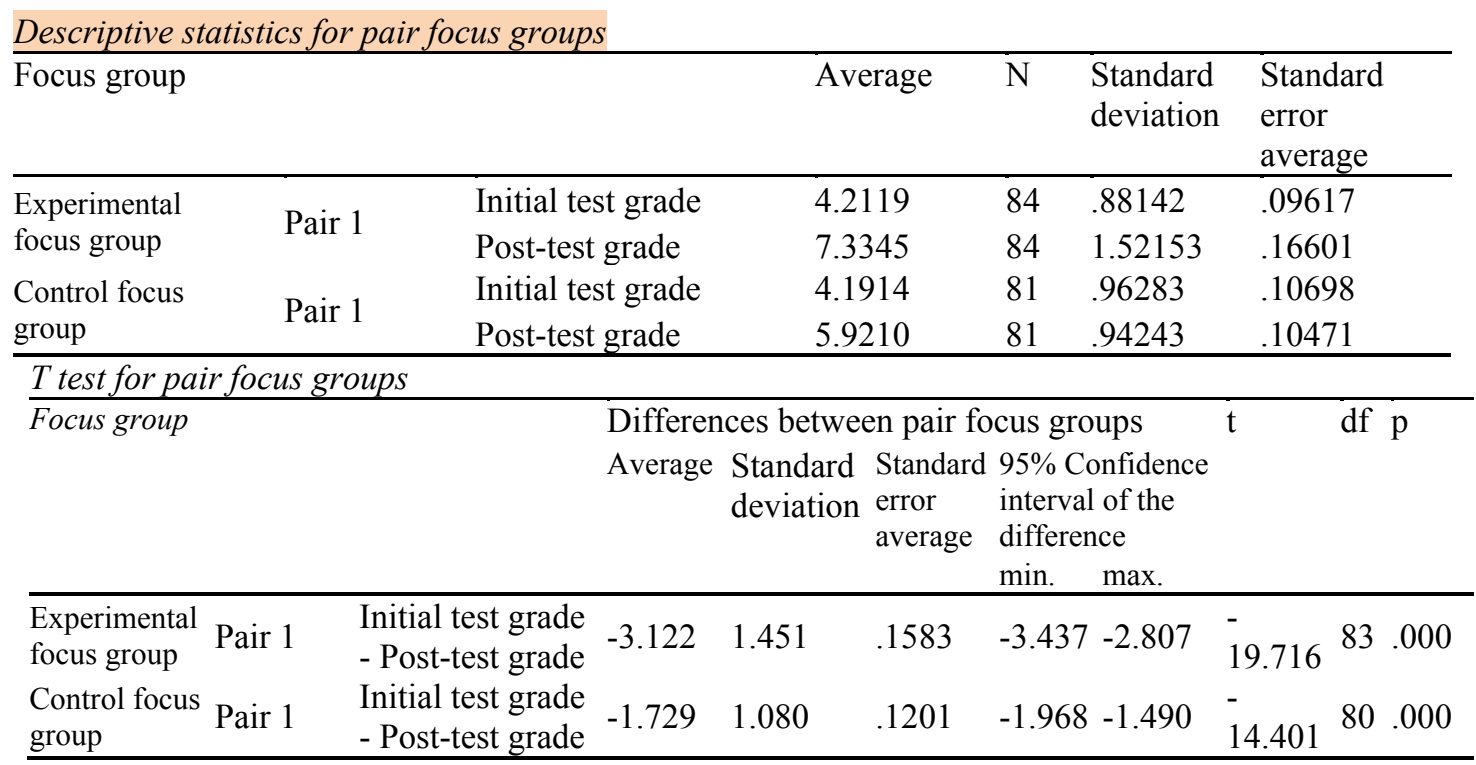

In order to compare the initial test grades with the post-test grades, we resorted to $t$ test for dependent focus groups (pairs).

The grades average at the initial test for the students in the experimental focus group was 4.21 and 4.19 for the students in the control focus group.

At post-test, students in the experimental focus group achieved a grades average of 7.33, whereas those in the control focus group reached a 5.92 average.

We considered the following hypotheses:

H0: there is no significant difference between the grades average at the initial test and the grades average at post-test.

H1: there is a significant difference between the grades average at the initial test and the grades average at post-test.
We determined that the grades average at both tests was significantly different, both for the experimental focus group $(\mathrm{t}=$ $19.716 ; \mathrm{df}=83 ; \mathrm{p}<0.001)$, as for the control focus group $(\mathrm{t}=-14.401$; $\mathrm{df}=80 ; \mathrm{p}<0.001)$

\section{Conclusion}

The achieved results entitle us to state that application of the educational programe, based on independent activities, which highlight the individual, collective, cognitive and meta-cognitive reflection, was much more efficient in improving the school performance, as compared to the classic methods.

We state the crucial role of independent activities within the study of high school pedagogy: 
- the independent activities may be used for reaching various educational purposes, namely certain fundamental objectives, such as: knowledge discovery, recording, systematisation, application, formation/consolidation of intellectual and practical skills and abilities;

- the independent activities imply cognitive, affective and emotional involvement from the students;

- the independent activities require self-information, selforganisation and self-monitoring of the learning activity;

\section{References}

Bocoş, M.-D. (coord.), Răduţ-Taciu, R., Stan, C., Chiș, O., Andronache D. (2015). Diç̧ionar praxiologic de pedagogie. Volum I: A-D. Piteşti: Paralela 45 Publishing House.

Bocoş, M.-D. (2013). Instruirea interactivă. Repere axiologice şi metodologice. Iaşi: Polirom Publishing House.

Bocoş, M. (2007). Teoria şi practica cercetării pedagogice. ClujNapoca: Casa Cărţii de Ştiinţă Publishing House.
- the independent activities highlight the individual, collective, cognitive and meta-cognitive reflection;

- the independent activities help at shaping and developing meta-cognitive competences;

- the independent activities valorise strategic learning (M.D. Bocoş, 2013).

*** (2002), Ministerul Educaţiei şi Cercetării, Consiliul Naţional pentru Curriculum, Programe şcolare pentru disciplinele pedagogice şi psihologice, aprobate prin Ordinul Ministrului nr. 4875 din 6.11.2002. 